\author{
BARBARA MAŁGORZATA KAŁDON \\ Uniwersytet Kardynała Stefana Wyszyńskiego \\ $w$ Warszawie
}

\title{
RODZINA JAKO INSTYTUCJA SPOLECZNA W UJĘCIU INTERDYSCYPLINARNYM
}

\section{FAMILY AS A SOCIAL INSTITUTION IN AN INTERDISCIPLINARY CONTEXT}

\section{Streszczenie}

Najważniejszym środowiskiem, w którym dziecko rozwija się i zaspokaja podstawowe potrzeby, jest rodzina. ${ }^{1}$ Według wielokrotnie prowadzonych badań opinii publicznej rodzina wciąż jeszcze znajduje się na czele wymienianych wartości, ${ }^{2}$ dlatego też temat ten wciąż nie traci na aktualności i cieszy się zainteresowaniem ze strony licznych teoretyków i badaczy tego zagadnienia $\mathrm{z}$ różnych dziedzin nauki, takich jak np.: prawo, pedagogika, psychologia, socjologia, teologia i wielu innych.

\section{Słowa kluczowe}

Rodzina, małżeństwo, dzieci, definicyjność interdyscyplinarna, prawo rodzinne.

\footnotetext{
${ }^{1}$ A. Szymanowska, Rodzina polska i jej rola w przeciwdziałaniu patologii młodzieży, [w:] IPSIR dzisiaj, Księga jubileuszowa (red. M. Porowski), Warszawa 1998, s. 495.

2 Np. komunikat z badań CBOS, Warszawa 2008, pt. Rodzina - przemiany wspótczesnej rodziny polskiej. Z badań tych wynika, że rodzina należy do najważniejszych wartości w życiu, a $92 \%$ respondentów stwierdziło, że rodzina jest potrzebna, aby człowiek był szczęśliwy.
} 


\section{Summary}

The family is the most important environment in which the child is developing and being nurtured.

According to many different surveys, family is still at the top of the mentioned values. This is why this topic will never leave its important position and will always be a source of interest to theoreticians and analysts from many different disciplines such as law, pedagogy, psychology, sociology, theology and many others.

\section{Key words}

Family, marriage, children, interdisciplinary definitions, family law.

\section{WPROWADZENIE}

Rodzina jest najstarszą grupą społeczną i występuje we wszystkich etapach rozwoju społeczeństwa i we wszystkich formacjach. Jest ona naturalnym i niezastapionym elementem struktury społecznej, nazywanej podstawową komórką społeczną. ${ }^{3}$ Jej szczególna rola polega na tym, iż rodzina jest naturalnym i niezastapionym środowiskiem narodzin i rozwoju człowieka, w niej zarówno dziecko, jak i osoba dorosła zaspokajają swoje podstawowe potrzeby. Ten naturalny charakter rodziny wynika przede wszystkim z tego, iż jest ona jedyną grupa społeczna, która rozwija się nie tylko przez przyjmowanie nowych członków z zewnątrz, ale także przez wewnętrzny rozwój - rodzenie dzieci. ${ }^{4}$ Rodzina jest $\mathrm{w}$ takim przypadku zjawiskiem nieprzemijającym, chociaż podlega ewolucji.

3 Art. 10 Międzynarodowego Paktu Praw Gospodarczych, Społecznych i Kulturalnych z 1966 roku, ratyfikowanego przez Polskę w 1977 roku.

${ }^{4}$ T. Smyczyński, Prawo rodzinne i opiekuńcze, Warszawa 2005, s. 1. 


\section{CHARAKTERYSTYKA TERMINU}

Samo pojęcie rodziny jest niełatwo jednoznacznie wyjaśnić. Może ono dotyczyć tylko rodziców i ich dzieci, jak również szerszego kręgu osób połączonych pochodzeniem od wspólnego przodka (więzami krwi) albo związanych wspólnością bytu ,pod jednych dachem." ${ }^{5}$ Odnośnie powyższej kwestii $\mathrm{w}$ socjologii sformułowano stosowne terminy: rodzina mała (nuklearna) skupiająca rodziców i ich dzieci oraz rodzina wielka obejmująca szerszy krąg krewnych, a zwłaszcza dziadków wraz z samodzielnym rodzeństwem należącym do wspólnego gospodarstwa domowego. ${ }^{6} \mathrm{~W}$ każdym bądź razie fundamentem rodziny w ujęciu zarówno socjologicznym, jak i prawnym jest para składająca się z mężczyzny i kobiety, a nie para płciowo jednorodna.

W socjologicznych definicjach rodziny najczęściej podkreśla się zadania, jakie ma ona spełniać. Do najważniejszych z nich należą: zapewnienie ciagłości biologicznej społeczeństwa oraz przekazywanie dziedzictwa kulturowego następnym pokoleniom.

MacIver, na którego powołuje się J. Szczepański (podobnie jak i na następnego autora) twierdzi, że rodzina to „grupa określona przez stosunki seksualne odpowiednio unormowane i trwałe, by mogła zapewnić rodzenie i wychowywanie dzieci." ${ }^{77}$ Podobnie Krickpatrick uważa za rodzinę ,instytucję zawierającą właściwe danej kulturze normy regulujące zachowania seksualne, reprodukcje gatunku, wychowanie dzieci i wzajemne stosunki różnych grup wyróżnionych według wieku, płci i wzajemnej pomocy." 8

Kolejnym elementem znajdującym się w owych socjologicznych definicjach rodziny jest wspólnota gospodarcza, czyli wspólnota zamieszkania. J. Szczepański określił rodzinę jako ,grupę złożoną z osób połączonych stosunkiem małżeństwa i stosunkiem rodzice-dzieci. Są to dwa

5 Tamże, s. 2.

6 F. Adamski, Socjologia matżeństwa i rodziny. Wprowadzenie, Warszawa 1982, s. 19.

7 J. Szczepański, Elementarne pojęcia socjologii, Warszawa 1963.

8 Tamże. 
podstawowe stosunki istniejące w rodzinie - małżeństwo oraz pokrewieństwo lub adopcja. Członkowie rodziny żyją zazwyczaj pod jednym dachem i tworzą jedno gospodarstwo domowe, które może obejmować dwa, lecz często i trzy pokolenia."

Najbardziej charakterystyczne cechy dla tych definicji, które wymienia powyższy autor podali McIver i Page stwierdzając, że rodzina jest grupa, która;

- obejmuje uznany społecznie typ trwałego obcowania płciowego,

- obejmuje instytucjonalną formę małżeństwa,

- zawiera pewien system nomenklatury wyrażającej stosunki pokrewieństwa i dziedziczenia,

- jest jednostką gospodarująca, to znaczy zapewniającą swym członkom utrzymanie i opiekę,

- zaspokaja potrzeby materialne i przygotowuje do samodzielnego życia,

- jest grupa mieszkającą wspólnie, tworzącą jedno gospodarstwo domowe. ${ }^{10}$

W oparciu o powyższe, można stwierdzić, że dochodzi się do definicji rodziny jako grupy społecznej, ale może być ona również traktowana w kategoriach instytucji społecznej.

Sens rodziny jako takiej instytucji sprowadza się przede wszystkim do pełnienia przez nią niezbędnych dla rozwoju społeczeństwa funkcji. Z. Zaborowski, na którego także powołuje się J. Szczepański, twierdzi, że rodzina jest ,grupą wychowawczą, rodzice są połączeni określonymi stosunkami wzajemnymi i relacjami z dziećmi, posiadający określone pozycje i role do realizacji norm i wartości, które uznają."11

Badacze traktujący rodzinę jako instytucję są zainteresowani relacjami między jej członkami. Oprócz definicji rodziny jako grupy społecznej oraz jako instytucji możemy pojmować ją jako system. Rodzina w tym kontekście jest ujmowana jako sposób organizacji społeczeństwa. Z psychologicznych definicji rodziny możemy wyróżnić $m$. in. definicję M. Przetacznikowej zawartą w pozycji J. Rembowskiego, według któ-

\footnotetext{
9 Tamże.

10 J. Szczepański, Elementarne ..., dz. cyt.

11 Tamże.
} 
rej „rodzina jest jedną z najważniejszych grup pierwotnych, to znaczy takich, które cechuje ścisły i bezpośredni kontakt ich członków: nawiązują oni ze sobą bliskie stosunki emocjonalne, łączą ich trwałe i osobiste więzy, oparte na współdziałaniu i solidarności."12 M. Ziemska natomiast mówi, że „rodzina jest małą grupą społeczną składającą się głównie z małżonków i ich dzieci. Stanowi ona całość, podlegającą dynamicznym przekształceniom związanym z biegiem życia jednostek, które wchodzą w jej skład. Opiera się na zastanych tradycjach społecznych i rozwija własne."13

J. Rembowski z kolei podaje, że rodzina to „grupa, która składa się z mężczyzny i kobiety złączonych małżeństwem, ich potomstwa (własnego lub adoptowanego) oraz w niektórych przypadkach z innych osób, najczęściej najbliższych krewnych"14, a E. Hurlock w książce powyższego autora zwraca uwagę na znaczenie rodziny dla rozwoju dziecka i definiuje ją jako „najważniejszy element więzi społecznych dziecka. Członkowie rodziny tworzą najbliższe otoczenie dziecka i są osobami najbardziej znaczącymi w pierwszych latach kształtujących jego życie."15

W słowniku pedagogicznym możemy odnaleźć następującą definiuję rodziny: ,rodzina jest małą grupą społeczną, składającą się z rodziców, ich dzieci i krewnych; rodziców łączy więź małżeńska, rodziców z dziećmi - więź rodzicielska, stanowiąca podstawę wychowania rodzinnego, jak również więź formalna określająca obowiązki rodziców i dzieci względem siebie." 16

Do głównych funkcji rodziny, które wymienia słownik pedagogiczny zalicza się:

1. funkcje prokreacyjne,

2. przygotowywanie dzieci do wejścia w życie społeczne, ich pielęgnowanie i wychowywanie oraz zapewnienie im odpowiedniego startu życiowego,

\footnotetext{
12 J. Rembowski, Rodzina w świetle psychologii, Warszawa 1986.

13 M. Ziemska, Rodzina a osobowość, Warszawa 1977.

14 J. Rembowski, dz. cyt.

15 Tamże.

16 Stownik pedagogiczny PWN, Warszawa 1987, s. 261-262.
} 
3. prowadzenie gospodarstwa domowego, zaspokajającego potrzeby członków rodziny,

4. sprawowanie pieczy nad życiem członków rodziny, ich zachowaniem, kultura, zdrowiem, trudnościami życiowymi. ${ }^{17}$

W Okoń w encyklopedii pedagogicznej rozróżnia jeszcze rodzinę niepełną (pozbawioną ojca lub matki) oraz rodzinę zastępczą (wychowującą dzieci, których rodzice nie żyją, bądź nie są w stanie ich wychowywać). ${ }^{18} \mathrm{~W}$ ujęciu pedagogicznym można także posłużyć się definicją S. Kawuli, według którego rodzina jest ,grupą społeczną, w której następuje poznanie pierwszych form etyczno-moralnych, rozróżnienie dobra i zła, klasyfikowanie osób, przedmiotów i zjawisk." 19

T. Plich i T. Wujke podają że w definicji rodziny jest położony nacisk na różne zadania i oczekiwania kierowane wobec niej. Można wyróżnić definicje, w których;

1. podkreśla się, że rodzina zapewnia społeczeństwu biologiczną całość i przekaz kulturowy,

2. nacisk jest położony na znaczenie wzajemnych relacji między członkami rodziny,

3. wprowadza się rozróżnienie pomiędzy rodziną, a grupą krewnych,

4. wprowadza się rozróżnienie pomiędzy gospodarstwem domowym, a rodziną traktowaną jako element składowy gospodarstwa,

5. jest jedyną grupą rozrodczą, co oznacza, że tylko rodzina rozmnaża się nie przez przyjmowanie członków z zewnątrz, ale przez rodzenie dzieci. (Utrzymuje zatem ciągłość biologiczna),

6. jest najważniejszą instytucją przekazującą podstawowy zrąb dziedzictwa kulturowego szerszych zbiorowości. ${ }^{20}$

Powszechnie przez rodzinę rozumie się parę małżeńską i ich dzieci. Przez rodzinę w takim ujęciu rozumie się ,grupę społeczną złożoną

\footnotetext{
17 Tamże.

18 W. Pomykało (red.), Encyklopedia pedagogiczna, Warszawa 1993.

19 S. Kawula, Funkcja opiekuńcza współdziałania rodziny, Białystok 1988.

20 T. Plich, T. Wujke, Człowiek dorosty w scenariuszu życia rodzinnego, Warszawa 1996.
} 
z małżonków i ich dzieci, a także osoby związane z nimi pokrewieństwem i powinowactwem." 21

Na rodzinę, jako podstawowy element struktury społecznej wskazywali już starożytni myśliciele i filozofowie. Arystoteles uważał za rodzinę podstawę struktury społeczeństwa. Powszechna Deklaracja Praw Człowieka uznaje rodzinę za naturalną i podstawową komórkę społeczeństwa. Tak samo Europejska Karta Społeczna, którą Polska ratyfikowała w 1997 roku, widzi w rodzinie podstawową komórkę społeczeństwa, z prawem do odpowiedniej ochrony społecznej, prawnej i ekonomicznej.

Najogólniej rzecz ujmując, rodzina jest instytucją ogólnoludzką, spotykaną we wszystkich epokach i kulturach. Do jej uniwersalnych wszędzie spotykanych zadań należy zaspakajanie elementarnych potrzeb życiowych jej członków, rodzenie i wychowywanie dzieci oraz zaspokajanie popędu seksualnego. Rodzina jest zbiorowością ludzi powiązanych ze sobą więzią małżeństwa, pokrewieństwa, powinowactwa lub adopcji. ${ }^{22}$

Współczesna definicja rodziny według M. Jurczaka brzmi: „Rodzina to podstawowa komórka wychowawcza, złożona z małżonków lub małżonków i dzieci, także ogół krewnych obojga małżonków. Rodzina odgrywa w społeczeństwie doniosłą rolę. W rodzinie obowiązuje całkowite równouprawnienie obojga małżonków. Powinni oni współdziałać dla dobra i zaspokojenia jej potrzeb. Szczególnie ważnym obowiązkiem małżonków jest opieka nad dziećmi i właściwe ich wychowanie." 23

W polskim prawie nie sformułowano definicji rodziny. Ustawodawca rzadko używa tego terminu, a odnośnie normy adresuje ją do określonych członków. Przede wszystkim rodzina jawi się jednak jako obiekt zainteresowania prawa dopiero wtedy, gdy została założona przez zawarcie małżeństwa. Faktyczne pożycie mężczyzny i kobiety (konkubinat) jest poza zasięgiem unormowań prawa cywilnego. $\mathrm{Z}$ kolei ustawodawstwo

${ }^{21}$ M. Jurczak, Leksykon. Wyrazy trudne, ważne i ciekawe, Warszawa 1977.

22 W. Pomykało (red.), Encyklopedia..., dz. cyt.

${ }^{23}$ M. Jurczak, Leksykon ..., dz. cyt. 
socjalne adresuje niekiedy pewne normy również do konkubentów, np. $\mathrm{w}$ zakresie pomocy społecznej. W pewnych państwach normuje się fragmentarycznie niektóre kwestie, zwłaszcza majątkowe, wynikające z pożycia konkubenckiego.

\section{POWSTANIE RODZINY}

Rodzina jako grupa społeczna, w której realizuje się współżycie pary ludzkiej i jej potomstwa, jest zarówno zjawiskiem socjologicznym, jak i prawnym. Rodzina powstaje zarówno wtedy, gdy mężczyzna i kobieta podejmują wspólne pożycie bez dopełnienia jakichś formalnych przesłanek, jak również w przypadku podjęcia tego współżycia przez zawarcie małżeństwa. Rodzina oparta na faktycznym pożyciu może realizować takie same funkcje, jednak tylko funkcje rodziny małżeńskiej są wsparte regulacją prawną. Dla przykładu można wymienić funkcję gospodarczą i opiekuńczą małżonków, którzy są zobowiązani przyczyniać się do zaspokajania potrzeb rodziny, a więc i potrzeb drugiego małżonka (art. 27 KRiO). Taki obowiązek nie istnieje między konkubentami. Podobnie tylko małżonkowie są zobowiązani do wzajemnej wierności, lojalności, wspierania się itd. Konsekwencje niedopełnienia tych obowiązków przewiduja przepisy KRiO o rozwodzie.

Polskie prawo rodzinne preferuje rodzinę opartą na małżeństwie, jednak nie oznacza to gorszej sytuacji dzieci zrodzonych ze związku pozamałżeńskiego. Preferencja ta kreuje natomiast stabilną sytuację małżonków na płaszczyźnie stosunków prawno-osobistych oraz majątkowych i pomija milczeniem związki konkubenckie. Preferencja rodziny małżeńskiej nie wynika $\mathrm{z}$ nadmiernego formalizmu czy z konserwatyzmu ustawodawcy. Chodzi bowiem o małżeństwo jako instytucję prawa świeckiego, ukształtowaną według założeń aksjologicznych danego systemu prawnego. Małżeństwo i rodzina są elementami ładu społecznego i porządku prawnego w państwie. Społeczeństwo jest w zasadzie sumą rodzin, co sprawia, że polityka społeczna i gospodarcza powinna mieć na względzie rodzinę, jako jednostkę konsumpcyjną, a niekiedy 
i produkcyjną. ${ }^{24}$ Poza tym sformalizowany kształt zawarcia małżeństwa i jego skutków zapewnia konieczną, ale minimalną kontrolę państwa nad powstaniem rodziny.

Małżeństwo zapewnia także jasną sytuację prawną samej pary małżonków względem siebie i względem osób trzecich spoza kręgu rodziny, a ponadto pozwala ustalić skład rodziny, a w szczególności ustalić pochodzenie jej członków. W interesie państwa i samych obywateli leży w takim razie umocnienie ustawodawcy o doniosłej, stabilizującej stosunki społeczne roli małżeństwa, jako elementu systemu prawnego. ${ }^{25}$

\section{SKEAD RODZINY}

Przynależność określonych osób do rodziny zależy od tego, jaką treść przypisuje się pojęciu rodziny i to zarówno w ujęciu socjologicznym, jak i prawnym.

W nowoczesnym społeczeństwie dominuje rodzina mała. W Polsce nierzadko spotyka się z faktem wspólnego zamieszkiwania rodziców $\mathrm{z}$ ich dorosłymi dziećmi, które założyły własną rodzinę. Taka wielka rodzina jest jednak skutkiem braku samodzielnych mieszkań, a nie zamierzoną organizacją życia rodzinnego. $Z$ kolei w środowisku rolniczym rodzina wielka, do której należą starzy rodzice, jest naturalnym skutkiem wymiany pokoleń w gospodarstwie rolnym.

KRiO niezmiernie rzadko posługuje się terminem rodzina; $w$ art. 27 mówi o grupie rodzinnej składającej się z małżonków i ich wspólnych dzieci (również przysposobionych). Z kolei art. $134 \mathrm{KRiO}$ wprowadza ograniczenie obowiązku alimentacyjnego rodzeństwa ze względu na utrzymanie najbliższej rodziny, co ma na względzie ochronę małżonka, dzieci, a ponadto także rodziców zobowiązanego do alimentacji.

Skład rodziny małej opiera się na stosunku prawnorodzinnym, jaki powstaje w wyniku zawarcia małżeństwa lub urodzenia dziecka. Ozna-

\footnotetext{
${ }^{24}$ T. Smyczyński, Prawo rodzinne..., dz. cyt. s. 4.

25 Tamże.
} 
cza to, iż do rodziny założonej przez małżonków należą nie tylko ich wspólne dzieci, ale i dziecko jednego z małżonków wychowujące się w rodzinnym gospodarstwie domowym. Przynależność dzieci wspólnych opiera się na pokrewieństwie z obojgiem małżonków, z kolei przynależność pasierba - na pokrewieństwie z jednym małżonkiem i na powinowactwie $z$ drugim. W nauce prawa możemy jednak odnaleźć przeważający pogląd opierający skład rodziny wyłącznie na biologicznym jej modelu. Prawnicze wyjaśnienie pojęcia rodziny nie może jednak pomijać stosunku prawnorodzinnego między jednym z małżonków, a niesamodzielnym dzieckiem drugiego małżonka. Obejmuje ono także dzieci przysposobione.

Od modelu prawnorodzinnego należy odróżnić społeczny model rodziny. Rekonstruuje się go w oparciu o więzi społeczne między członkami rodziny, zwłaszcza na płaszczyźnie pomocy w zakresie utrzymania i wychowania. $Z$ tego też względu do rodziny proponuje się włączyć również dzieci obce, przyjęte na utrzymanie i wychowanie w zakresie podjętych obowiązków rodziny zastępczej. Nie ma tu jednak stosunku prawnorodzinnego, ale dziecko znajduje się w sytuacji podobnej do sytuacji rodzinnej.

W literaturze i praktyce używa się ponadto terminu socjologicznego „rodzina niepełna”, oznaczającego rodzinę, w której brakuje jednego $\mathrm{z}$ rodziców.

\section{PRAWNA OCHRONA RODZINY}

Wypełnianie zadań przez rodzinę sprawia, że obowiązujące prawo stara się chronić rodzinę i wypełniane przez nią zadania.

Głównym pod tym względem unormowaniem jest przepis art. 18 obowiązującej konstytucji Rzeczpospolitej Polskiej. ${ }^{26}$ który wśród podstawowych zasad ustrojowych wymienionych w rozdz. I tej konstytucji ustanawia taką regułę, jak: „Małżeństwo jako związek kobiety i mężczyzny, rodzina, macierzyństwo i rodzicielstwo znajdują się pod

${ }^{26}$ Konstytucja RP z dnia 2 kwietnia 1997 r. 
szczególną ochroną i opieką Rzeczpospolitej Polskiej." Cytowana konstytucyjna zasada ochrony państwa nad rodziną, a także inne przepisy konstytucyjne, dotyczące rodziny, stanowią podstawę dla licznych unormowań określających pozycje prawne rodziny w społeczeństwie.

W regulacjach zapewniających ochronę praw i prawidłowe funkcjonowanie rodziny ważną rolę odgrywają niewątpliwie przepisy prawa karnego. Jak słusznie jednak stwierdza T. Szymanowski, prawo karne odnośnie ochrony rodziny spełnia tylko rolę pomocniczą, która polega na zastosowaniu reakcji prawno-karnej na fakt popełnienia przestępstwa, wskazaniu społeczeństwu, jakie zachowania godzące w dobro rodziny są na tyle szkodliwe, że spotkają się z represją karną, jak również lagodzą w pewnym stopniu skutki popełnienia przestępstwa. ${ }^{27}$ Miejsce dla prawa karnego powinno się ograniczyć do czynów, które stanowią niewątpliwie precyzyjnie określone przestępstwo, a orzeczenie kar będzie miało sens wówczas, gdy wyczerpano już wszelkie środki opieki, leczenia, pomocy i poradnictwa, albo wtedy gdy popełniono poważne przestępstwo przeciwko rodzinie. ${ }^{28}$

Głównym przestępstwem przeciwko rodzinie, niezmiernie szkodliwym społecznie jest przestępstwo znęcania się, uregulowane w art. 207 k.k. ${ }^{29}$ Zakres możliwych stanów faktycznych przewidzianych dla przestępstwa znęcania się obejmuje szereg przestępstw przewidzianych w k.k. (np. groźba karalna), jednakże z uwagi na zamiar sprawcy wraz $\mathrm{z}$ określoną $\mathrm{w}$ owym przepisie ofiarę są one przyporządkowane do art. $207 \S 1$ k.k. ${ }^{30}$ Ochrona prawno-karna dzieci jest ponadto w pewnym stopniu zawarta w art. $200 \S 1$ k.k., który odnosi się do doprowadzenia małoletniego poniżej 15 lat do obcowania płciowego lub do poddania się innej czynności seksualnej, a także do art. $204 \S 3$ dotyczącego nakłaniania małoletniego do uprawiania prostytucji lub czerpania $\mathrm{z}$ tego

\footnotetext{
27 T. Szymanowski, Prawno-karna ochrona rodziny ze szczególnym uwzględnieniem najnowszych unormowań dotyczacych przestęstw agresywnych, tekst przygotowany do druku.

28 Tamże.

29 Kodeks Karny z 1997r. (Dz. U. Nr 88. poz. 553)

30 T. Szymanowski, Prawno - karna ochrona, tamże.
} 
korzyści. Powyższe czyny często są popełniane z użyciem przemocy, a zawarte są one w rozdz. XXV k.k. zawierającym przestępstwa przeciwko wolności seksualnej i obyczajności, jednakże jak widać, godzą one także w interesy dzieci, a zatem i rodziny. ${ }^{31}$ Oprócz wspomnianych przestępstw przeciwko członkom rodziny można także popełnić inne przestępstwa agresywne, np. zgwałcenie osób (art. 197 k.k.) czy kazirodztwo (art. 201 k.k.). Poza tym należy zwrócić uwagę na to, iż liczne unormowania przyczyniające się do utrzymania spoistości rodziny skazanego na karę pozbawienia wolności w czasie odbywania kary są zawarte w kodeksie karnym wykonawczym. ${ }^{32}$

Ponadto w kodeksie postępowania karnego można odnaleźć przepisy służące ochronie rodziny (np. art. $182 \S 1$ czy art. $183 \S 4) .{ }^{33}$

Odnośnie definicji przemocy w rodzinie autorka opowiada się za definicją zawartą $\mathrm{w}$ ustawie o przeciwdziałaniu przemocy $\mathrm{w}$ rodzinie z dnia 29 lipca 2005 roku, ${ }^{34}$ według której przez przemoc w rodzinie należy rozumieć jednorazowe albo powtarzające się umyślne działanie lub zaniechanie naruszające prawa lub dobra osobiste członków rodziny, w szczególności narażające te osoby na niebezpieczeństwo utraty życia, zdrowia, naruszające ich godność, nietykalność cielesną, wolność, w tym wolność seksualną, powodujące szkody na ich zdrowiu fizycznym lub psychicznym, a także wywołujące cierpienia i krzywdy moralne u osób dotkniętych przemocą.

\section{PODSUMOWANIE}

Rodzina jako podstawowa instytucja wychowawcza jest wartością uniwersalną. Przeto domaga się szacunku w respektowaniu jej praw i obowiązków. Wszelkie działania przeciw rodzinie i jej członkom jest aktem skierowanym nie tylko względem jej samej ale także całemu społeczeństwu obywatelskiemu.

\footnotetext{
31 T. Szymanowski, Prawno - karna ochrona, tamże.

32 Kodeks karny wykonawczy z 1997r. (Dz. U. Nr 90. poz. 557).

33 Kodeks postępowania karnego z 1997r. ( Dz. U. Nr 89. poz. 555).

34 Dz. U. Nr 180, poz. 1493.
} 


\section{BIBLIOGRAFIA}

Adamski F., Socjologia matżeństwa i rodziny. Wprowadzenie, Warszawa 1982.

Art. 10 Międzynarodowego Paktu Praw Gospodarczych, Społecznych i Kulturalnych z 1966 r. ratyfikowanego przez Polske w 1977 r.

Jurczak M., Leksykon. Wyrazy trudne, ważne i ciekawe, Warszawa 1977.

Kawula S., Funkcja opiekuńcza wspótdziałania rodziny, Białystok 1988.

Kodeks Karny z 1997r. (Dz. U. Nr 88. poz. 553).

Kodeks karny wykonawczy z 1997r. (Dz. U. Nr 90. poz. 557).

Kodeks postępowania karnego z 1997r. ( Dz. U. Nr 89. poz. 555).

Komunikat z badań CBOS, Warszawa 2008r., pt. Rodzina - przemiany współczesnej rodziny polskiej.

Konstytucja RP z dnia 2 kwietnia 1997r.,

Plich T., Wujke T., Człowiek dorosty w scenariuszu zycia rodzinnego, Warszawa 1996.

Pomykało W. (red.), Encyklopedia pedagogiczna, Warszawa 1993.

Rembowski J., Rodzina w świetle psychologii, Warszawa 1986.

Stownik pedagogiczny PWN, Warszawa 1987.

Smyczyński T., Prawo rodzinne i opiekuńcze, Warszawa 2005.

Szczepański J., Elementarne pojęcia socjologii, Warszawa 1963.

Szymanowska A., Rodzina polska i jej rola w przeciwdziałaniu patologii młodzieży, [w:] IPSIR dzisiaj, Ksiega jubileuszowa pod red. M. Porowskiego, Warszawa 1998.

Szymanowski T., Prawno-karna ochrona rodziny ze szczególnym uwzględnieniem najnowszych unormowań dotyczacych przestępstw agresywnych, tekst przygotowany do druku.

Ustawa o przeciwdzialaniu przemocy $w$ rodzinie $z$ dnia 29 lipca 2005 r., (Dz. U. nr 180, poz. 1493).

Ziemska M., Rodzina a osobowość, Warszawa 1977. 